EPiC Series in Language and Linguistics
Volume 3, 2018, Pages 27-32
LSP in Multi-disciplinary contexts of
Teaching and Research. Papers from the
16th International AELFE Conference

\title{
CLIL and academic vocabulary: a preliminary study of secondary-school learners' academic vocabulary size
}

\author{
Irene Castellano-Risco ${ }^{\mathrm{a}}$ \\ ${ }^{a}$ Universidad de Extremadura, Facultad de Formación del Profesorado, Campus Unicersitario, Av. De la \\ Universidad, s/n, 10071 Cáceres, España
}

\begin{abstract}
Since their eruption in the European Educational Systems panorama, the use of CLIL (Content and Language Integrated Learning) approaches has widely spread all throughout Europe, resulting in a revolution in foreign language teaching approaches (Coyle, Hood, Marsh, 2010; Mehisto, Marsh \& Frigols, 2008; Pérez Cañado, 2012; Ruiz de Zarobe \& Jiménez Catalán, 2009). This situation has set off a plethora of studies with two different foci: on the one hand, researchers have attempted to clarify the CLIL phenomenon, developing a theoretical framework (Coyle, 2006, 2007; Coyle, Hood \& Marsh, 2010; Mehisto, Marsh \& Frigols, 2008; Pérez-Cañado, 2012). On the other hand, other studies have attempted to identify its main advantages and drawbacks. This latter trend has reported clear benefits of using CLIL approaches in terms of vocabulary learning, L1 transfer (Agustín Llach, 2009) and fluency (Ruiz de Zarobe, 2008) among others. However, although CLIL approaches are developed in academic settings, most of the studies focusing on the area of vocabulary research have concentrated on learners' general receptive vocabulary size in relation to the CLIL practice (Canga Alonso, 2013; Canga Alonso, 2015; Jiménez Catalán \& Ruiz de Zarobe, 2009) and have neglected the analysis of the academic vocabulary.

This paper presents a preliminary study on the academic vocabulary and its interaction with the educational approach (CLIL vs English as a Foreign Language) of two groups of secondary-school learners. 138 students in their $4^{\text {rd }}$ year of secondary education took part in this study. They were asked to answer the Academic band of the Vocabulary Levels Tests (Schmitt, Schmitt, and Clapham 2001) and the data obtained were compared looking into differences according to the kind of approach. Pearson's correlation coefficient was used for pinpointing significant correlations. As expected, results show significant discordances as regards academic vocabulary size, revealing larger size of academic vocabulary for the CLIL learners.
\end{abstract}

Keywords: Receptive academic vocabulary size, Vocabulary Levels Tests, CLIL, secondary school.

A. Curado (ed.), AELFE2017 (EPiC Series in Language and Linguistics, vol. 3), pp. 27-32 


\section{Introduction}

In last decades, a new language learning approach, Content and Language Integrated Learning approach, has arrived to the Spanish Educational System panorama. This new approach advocates the use of Foreign Languages in content subjects with a dual-focused objective: the development of a foreign language while mastering the subject matter (Coyle, 2006, 2007; Coyle, Hood \& Marsh, 2010; Ball, Kelly \& Clegg, 2015; Mehisto, Marsh \& Frigols, 2008).

Vocabulary seems to be one of the language aspects which most benefots from these approaches. A large amount of research has been conducted in order to identify CLIL benefits in lexical development. However, most of them has focused on productive and receptive general size (Agustín Llach, 2009; Arribas, 2016; Canga Alonso, 20013, 2015; Castellano-Risco, 2017; Jiménez Catalán \& Terrazas Gallego, 2005; Jiménez Catalán \& Ruiz de Zarobe, 2009; Ruiz de Zarobe, 2008), dismissing the importance of academic vocabulary size in CLIL contexts. Academic vocabulary is made up of those words frequent in all kinds of academic subject areas (Nation, 2001). Bearing into account that CLIL approaches are applied in academic contexts, it may seem reasonable that the greatest differences between CLIL approaches and others could be found in this type of vocabulary. Therefore, the main aim of this research is to analyze the impact of CLIL approaches on receptive academic vocabulary size.

\section{Method.}

\subsection{Research questions}

RQ1: Does the language learning approach have an influence on the academic vocabulary size of secondary-school learners?

RQ2: Does the amount of hours of exposure to the Foreign Language have any impact on the academic vocabulary size of secondary-school learners?

\subsection{Context}

This study took place in Extremadura, where the 'Bilingual Sections' program, based on CLIL principles, started to be officially regulated in the 2004-2005 academic year. Since its creation, the number of schools with bilingual sections has been increasing exponentially each year since then, up to the 270 bilingual sections in the 2015-2016 academic year.

In order to implement the bilingual sections project efficiently, the educational authorities of the region have established some regulations (DOE, 2013), such as establishing the foreign languages that can be used -English, French or Portuguese-, the number of content areas, the roles of the teachers, and demanding some requirements of the teachers regarding their methodology and language knowledge (for more detailed information, see Alejo and Piquer-Píriz, 2010, 2016a, 2016b).

\subsection{Design of the Study}

\subsubsection{Treatment}

The sample of this study consisted of 138 fourth grade Secondary Education students. Eighty-two of them were enrolled in a CLIL program and the other fifty-six students followed a mainstream English as a Foreign Language (EFL) program. 
As can be seen in Table 1, sample have been clustered into four groups, not only taking into account the teaching approach followed but also the amount of hours of exposure to English:

- EFL group: this group was made up of fifty-six learners who were only exposed to English in the EFL subject. They started to attend EFL when they were in $1^{\text {st }}$ year of Pre-Primary school.

- CLIL 1 group: this group had participated in CLIL experiences since they were in $1^{\text {st }}$ Year of Primary Education and consisted of twenty-three learners.

- CLIL 2 group: it encompassed twenty-five learners who started to be in CLIL sections in $4^{\text {th }}$, $5^{\text {th }}$ and $6^{\text {th }}$ Year of Primary Education.

- CLIL 3 group: This group is the most numerous CLIL group with thirty-four students. These learners started to be involved in CLIL experiences when they started in secondary school, therefore, they received only EFL input in Primary Education, and then, in Secondary School, their amount of input increased, as they were not only exposed to more hours of EFL subject but to content subjects taught through English too.

Table 1. Comparison among groups in relation to the hours of instructions and subjects taught through English.

\begin{tabular}{ccccc}
\hline & EFL group & CLIL 1 group & CLIL 2 group & CLIL 3 group \\
\hline $\begin{array}{c}\text { N } \\
\text { Hours of } \\
\text { instruction }\end{array}$ & 56 & 23 & 25 & 34 \\
\hline
\end{tabular}

\subsubsection{Data Gathering Instrument}

In order to measure receptive academic vocabulary size, the Academic band of the Vocabulary Levels Tests was used. This form-recognition test was developed by Schmitt, Schmitt and Clapham (2001) and consists of five different levels. In each level, ten clusters are presented, each of which is made up of three definitions and six words. Test-takers are asked to match the definitions with the corresponding word. Focusing on the Academic level, it was developed following the Academic Word List (Coxhead, 1984), so, it is not based on frequency levels as the rest of levels of the text, but it only analyzes the knowledge of this list.

\subsubsection{Data collection procedure}

The test was administered in one session during school time on February, 2017. At the beginning of the tests, clear instructions in both English and Spanish and together with examples were given.

Test were corrected and total scores obtained, ranging from $0 \%$ to $100 \%$. Data were analyzed with SPSS 22 to check whether there were statistically significant differences according to the type of instruction.

\section{Results and Discussion}

After having presented the theoretical framework of this study and the methodology used to carry out the research, this section presents the results that were obtained and discusses them below in relation to the research questions posed for the study.

In order to provide answers to the research questions, results will be presented as percentages of words that learners seem to recognize. The following Table 2 shows the mastery of the Academic Word list in the two groups of students: 
CLIL and academic vocabulary: a preliminary study of secondary-school ...

I. Castellano-Risco

Table 2. Receptive academic vocabulary size results.

\begin{tabular}{ccc}
\hline & EFL group & CLIL group \\
\hline $\mathrm{N}$ & 56 & 82 \\
Hours of & & \\
instruction & 1,333 & 2,402 \\
Academic VLT & & $76.83 \%$ \\
mean & $40.76 \%$ & \\
\hline
\end{tabular}

As shown in the table, CLIL students (76.83\%) obtained higher results than their EFL counterparts $(40.76 \%)$ did. Therefore, a difference between both group of learners was observed. When inferential statistics were applied, a significant difference was found between both CLIL and EFL learners' academic vocabulary size. Moreover, a Pearson's $r$ found positive correlations $(\mathrm{N}=138, \mathrm{p} .<.05)$ between presenting a larger receptive academic vocabulary size and being enrolled in a CLIL program.

Many reasons can be behind this connection. Factors such as the amount of exposure to the foreign language, the range of vocabulary the learners are exposed to and the fact that CLIL learners had to pass an exam before becoming CLIL learners have been traditionally attributed to this difference.

In order to examine the role of the hours of exposure in these results, data is going to be analyzed now taking into account the amount of exposure. Thus, the four groups presented in Section 2.3.1. are going to be compared.

Table 3. Results in relation to the hours of instruction

\begin{tabular}{ccccc}
\hline & EFL group & CLIL 1 group & CLIL 2 group & CLIL 3 group \\
\hline $\mathrm{N}$ & 56 & 23 & 25 & 34 \\
$\begin{array}{c}\text { Hours of } \\
\text { instruction }\end{array}$ & 1,330 & 3,165 & 2,565 & 2,165 \\
$\begin{array}{c}\text { Academic } \\
\text { VLT mean }\end{array}$ & 40.76 & 80.58 & 79.29 & 73.33 \\
\hline
\end{tabular}

As can be determined by the data, those learners with greater amount of exposure to English obtained higher score means. These results seem to show a relation between the time of exposure and the receptive academic vocabulary size. In fact, when inferential statistics were applied, a Pearson's $r$ found a moderate positive correlation $(\mathrm{N}=138, \mathrm{p} .<.05)$ between having a larger receptive academic vocabulary size and being in a bilingual section for a longer period of time.

However, when analyzing the differences among groups statistically, differences between the EFL group and the rest of groups were found, but differences among the CLIL groups could not be defined as statistically significant. In other words, although it seemed to be clear that there is some kind of relation between the amount of exposure and the receptive academic vocabulary size, it does not seem to be the main reason for the difference between CLIL and EFL results. In fact, although a significant difference was found between CLIL 3 and EFL groups, the difference as regards the hours of instruction is smaller than the difference between CLIL 3 and CLIL 1, in which significant differences in receptive academic vocabulary size were not found. 


\section{Conclusion}

In light of the results, there is a clear distinction in the academic vocabulary size when comparing different types of instruction-CLIL and mainstream EFL. CLIL learners present a significant larger size of academic vocabulary in comparison to their EFL counterparts.

Differences between CLIL and EFL learners' vocabulary sizes have been continually related in the literature to the difference in the amount of hours of instruction. However, our results reveal that, although a larger exposure to English seems to benefit vocabulary size, this may not be the only factor involved, as, when analysing CLIL groups with different amount of English input, differences among them are not statistically significant. Therefore, other factors, such as the CLIL approach itself, the kind of input learners are exposed to or the placement tests CLIL learners have to pass to become a part in the bilingual sections, seem to influence in a greater extent the vocabulary size CLIL learners obtain.

Thus, the main conclusion in this study is that the fact of being enrolled in a CLIL program seems to have a clear positive impact not only on receptive vocabulary size as other studies conclude (Agustín Llach, 2009; Canga Alonso \& Arribas García, 2014; Canga Alonso, 20013, 2015; Castellano-Risco, 2017; Jiménez Catalán \& Terrazas Gallego, 2005; Jiménez Catalán \& Ruiz de Zarobe, 2009; Ruiz de Zarobe, 2008), but also on receptive academic vocabulary size, nevertheless the amount of hours of exposure to English.

\section{References}

Alejo, R. \& Piquer-Píriz, A. (2010). CLIL Teacher Training in Extremadura: A Needs Analysis Perspective. In D. Lasagabaster $\&$ Y. Ruiz de Zarobe (Eds.), CLIL in Spain: Implementation, Results and Teacher Training (pp. 219-242). Cambridge: Cambridge Scholars Publishing.

- (2016a). Urban vs. rural CLIL: an analysis of input-related variables, motivation and language attainment. Language, Culture and Curriculum. DOI:10.1080/07908318.2016.1154068

- (2016b). Measuring the productive vocabulary of secondary school CLIL students: Is Lex30 a valid test for low-level school learners? Vigo International Journal of Applied Linguistics, 13, 31-54.

Agustín Llach, M.P. (2009). The Role of Spanish L1 in the Vocabulary Use of CLIL and non-CLIL EFL Learners. In R. M. Jiménez Catalán, \& Y. Ruiz de Zarobe (Eds.), Content and language integrated learning: Evidence from research in Europe (pp. 112-130). U.K.: Multilingual Matters.

Ball, P.; Kelly, \&. Clegg, J.K. (2015). Putting CLIL into Practice. Oxford: Oxford University Press.

Boers, F., \& Lindstromberg, S. (2008). How cognitive linguistics can foster effective vocabulary teaching. In Boers, Frank/ Lindstromberg, Seth (Eds.), Cognitive Linguistic Approach to Teaching Vocabulary and Phraseology. Berlin: Mouton, The Hague, 1-65.

Canga Alonso, A., \& Arribas García, M. (2014). Productive vocabulary knowledge of Spanish EFL learners. RAEL: revista electrónica de lingüistica aplicada, 12(1), 39-56.

Cangas Alonso, A. (2013). Receptive vocabulary size of secondary Spanish EFL learners. Revista de Linguisticas y Lenguas Aplicadas, 8, 66-75.

Canga Alonso, A. (2015). Receptive Vocabulary of CLIL and Non-CLIL Primary and Secondary School Learners. Complutense Journal of English Studies, 23, 59-77.

Castellano-Risco, I. (2017). Cómo el uso de un enfoque AICLE puede afectar al vocabulario receptivo en estudiantes de secundaria. In G. Nieto Caballero (Ed.), Nuevas aportaciones al studio de la enseñanza y aprendizaje de lenguas (pp. 137-149). Extremadura: Servio de Publicaciones de la Universidad de Extremadura.

Coyle, D. (2006). Developing CLIL: towards a theory of practice, APAC Monographs, 6. CLIL in Catalonia, from theory to practice, 5-29.

Coyle, D. (2007). CLIL: towards a connected research agenda for CLIL pedagogies. International Journal of Bilingual Education and Bilingualism, 10 (5),543-562.

Coyle, D., Hood, P., \& Marsh, D. (2010). CLIL: Content and Language Integrated Learning. Cambridge: Cambridge University Press.

Coxhead, A. (2000). A New Academic Word List. Tesol quarterly, 32(2), 213-238.

Jiménez Catalán, R. M., \& Terrazas Gallego, M. (2005). The receptive vocabulary of English Foreign Language young learners. 
Journal of English Studies, 5, 173-192.

Jiménez Catalán, R. M., \& Ruiz de Zarobe, Y. (2009). The receptive vocabulary of EFL learners in two instructional contexts: CLIL versus non-CLIL learners. En Jiménez Catalán, Rosa María./ Ruiz de Zarobe, Yolanda (Eds.), Content and language integrated learning: Evidence from research in Europe (pp. 81-93). Bristol: Multilingual Matters.

Junta de Extremadura (2013). ORDEN de 27 de mayo de 2013 por la que se regula, con carácter experimental, la convocatoria de Secciones Bilingües en Educación Primaria, Educación Secundaria Obligatoria y Formación Profesional para el curso 2013/2014, en centros sostenidos con fondos públicos de la Comunidad Autónoma de Extremadura. Diario Oficial de Extremadura, 106, 12679-12708.

Nation, P. (2001). Learning Vocabulary in Another Language. Cambridge: Cambridge University Press.

Mehisto, P., Marsh, D., \& Frigols, M. J. (2008). Uncovering CLIL: Content and Language Integrated Learning and Multilingual Education. Oxford: Macmillan Education.

Pérez Cañado, M.L. (2012). CLIL research in Europe: Past, present and future. International Journal of Bilingual Education and Multilingualism, 15 (3), 315-341.

Ruiz de Zarobe, Y. (2008). CLIL and foreign language learning: A longitudinal study in the Basque Country. International CLIL Research Journal, 1, 60-73.

Schmitt, N., Schmitt, D., \& Clapham, C. (2001). Developing and exploring the behaviour of two new versions of the Vocabulary Levels Test. Language Testing 18 (1), 55-88. 